\title{
Optimal Thickness of the Heat Insulation Layer for the External Walls
}

\author{
Alexander Gorshkov \\ Department of Intellectual Systems and Information Security, Institute of Information Technologies and Automation, Saint-Petersburg State \\ University of Industrial Technologies and Design, Saint-Petersburg, Russia
}

\section{Email address: \\ alsgor@yandex.ru}

\section{To cite this article:}

Alexander Gorshkov. Optimal Thickness of the Heat Insulation Layer for the External Walls. Landscape Architecture and Regional Planning. Vol. 4, No. 2, 2019, pp. 28-35. doi: 10.11648/j.larp.20190402.12

Received: January 16, 2019; Accepted: March 12, 2019; Published: October 23, 2019

\begin{abstract}
The paper presents the methodology for calculating the heat energy losses via external walls of apartment building before and after additional heat insulation of the facades using mineral wool insulation. Normally, a higher level of thermal insulation of external enclosing structures is provided by a greater thickness of the thermal insulation layer. Additional insulation thickness requires additional investment. The higher the level of thermal insulation of external walling, the less heat is lost through the walls. Therefore, energy saving measures should be considered not only from a technical point of view, but also from an economic point of view. Based on the known parameters of the duration of heating period, investments for additional insulation of the facades in the considered apartment building and values of the operating costs for heating before and after the facades insulation, an estimation of the predicted payback period was evaluated for various thickness of the additional thermal insulation layer $(50,60,70,80,90,100,110,120,130,140,150,160,170,180,190,200,250,300$ and 350 $\mathrm{mm}$ ). For the considered object an optimal thickness of the additional heat insulation layer is calculated. For that optimal thickness, payback period, calculated with account for heating energy tariffs growth rates and discounted future cash flows, takes its minimal value.
\end{abstract}

Keywords: Apartment Building, External Wall, Insulation, Thermal Energy, Transmission Losses, Energy Saving Investments, Payback Period, Energy Efficiency

\section{Introduction}

In 2014-2017 in Russia there was a state program of citizens relocation from old houses and houses under the threat of collapse.

On the Fund for Promotion Housing and Communal Services Reforming web site (https://www.reformagkh.ru/relocation) one can find a list of dwelling houses considered to be under the threat of collapse. One of such houses was brought into operation in town of Porkhov, Pskov region.

Construction is funded by the means of State corporation Fund for Promotion Housing and Communal Services Reforming and Regional budget funds. Within the allocated funds frameworks, as a rule, initial project documents provide only those energy savings measures which covered by current laws. Minimal energy savings measures are usually not enough for achieving high energy efficiency indicators.

In order to increase energy efficiency of the dwelling house being built in town of Porkhov, UNDP-GEF has provided technical support, i.e. funds to be used to increase energy efficiency of the dwelling house.

Technical support is provided within the framework of the UNDP-GEF 00074315 «Energy Efficiency of Buildings on North-West of Russia» (referred further as UNDP-GEF). According to UNDP conditions, the amount of the technical support cannot exceed $20 \%$ of the overall sum provided for the construction of demo building.

It is known that more than a third of the total heat consumption is used for heating buildings. One of the ways to reduce heating energy losses is an additional heat insulation of building envelope (walls, surfaces, attics slabs, external doors etc.). Increasing heat insulation level leads to reduction of transmission losses of heating energy through the building envelope. 
Therefore, heating insulation leads to reduction of energy consumed, and as a consequence, to reduction of heating fees. This is the approach on which an economic effect of considered energy saving measure implementation is based.

Implementation of any energy saving measure usually requires additional investments. Economic efficiency of energy saving measures implemented in a building may be characterized by its predicted payback period.

The criteria for return on investment are discussed in detail in the papers [1-13]. This study considers the model of the recoupment of investments in energy saving proposed in [14, $15]$.

\section{Research Object}

Research object is an apartment building located in the town of Porkhov, Pskov Region.

Main characteristics of the buildings:

(1) Number of floors - 3 (including ground floor)

(2) Number of entrance halls -2

(3) Number of apartments -42

(4) Total space $-2083,33$ sq. m.

(5) Facades area $A_{f a c}-1162,77$ sq. m.

(6) Floor height $-3 \mathrm{~m}$

(7) Floor slabs - multiple cavity precast reinforced concrete

(8) Roof - V-shaped on wooden structures

(9) Attic floor - without heating (cold)

(10)Basement - with allocated individual heating point.

According to the initial project, external walls of the building are supposed to be made of autoclaved aerated concrete (AAC) blocks with density of D500 and thickness of $375 \mathrm{~mm}$ with following plastering without an additional insulation (figure 1).

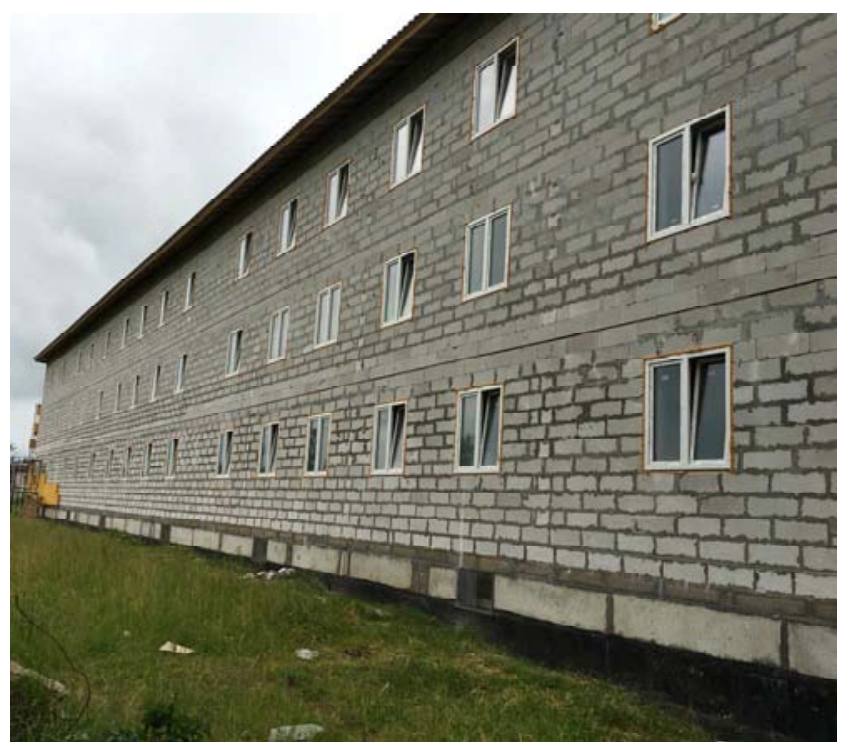

Figure 1. External walls before the insulation works.

Thermal mapping of the facades during winter period of service/operation showed the existence of many heatconducting fractions (figures 2-5). Due to that, it was decided to provide additional insulation to the external walls to increase heat conducting resistance and to rise heat engineering homogeneity of the facades.
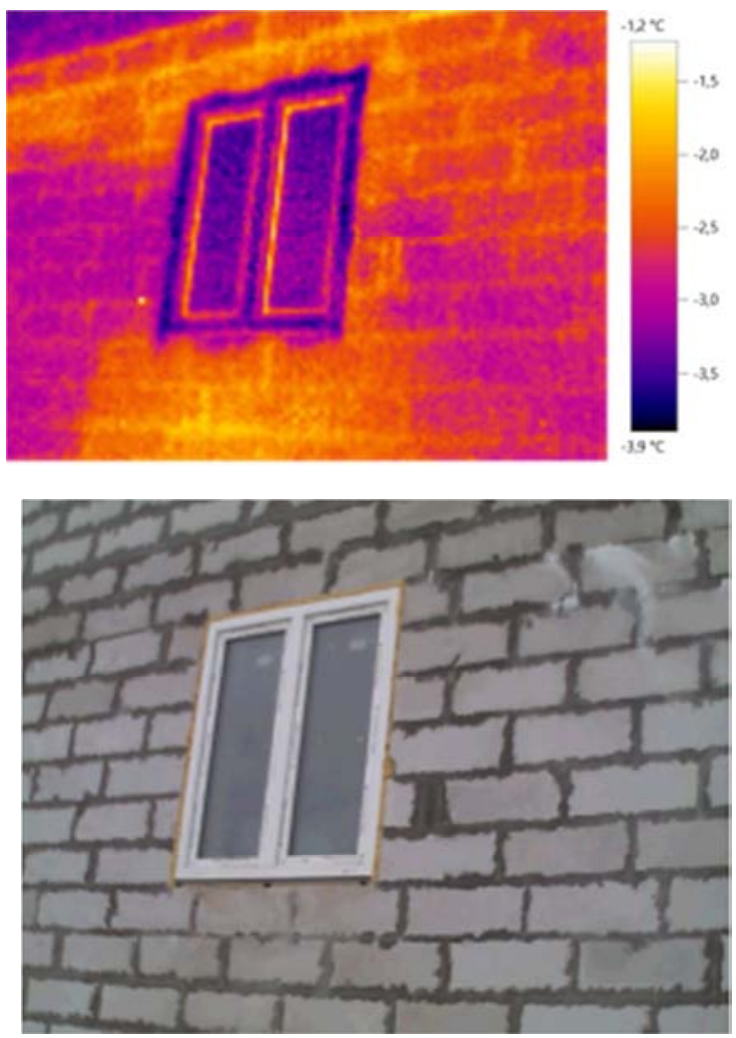

Figure 2. Heat-conducting fractions around window openings.
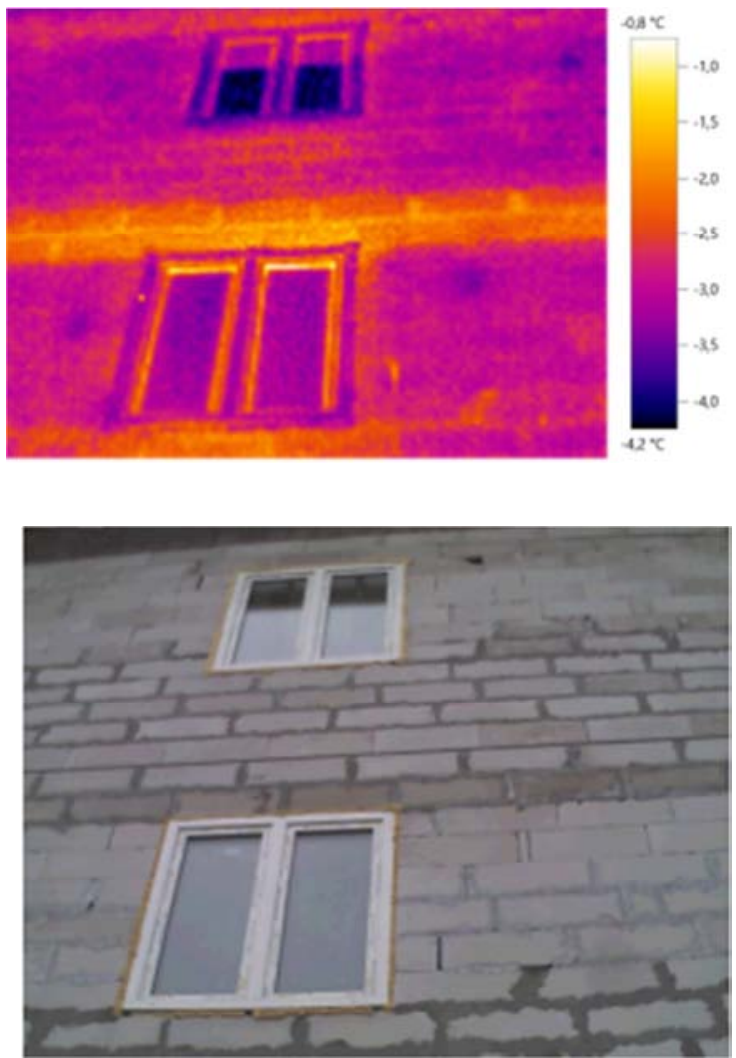

Figure 3. Heat-conducting fractions in the floor slabs levels/layer. 

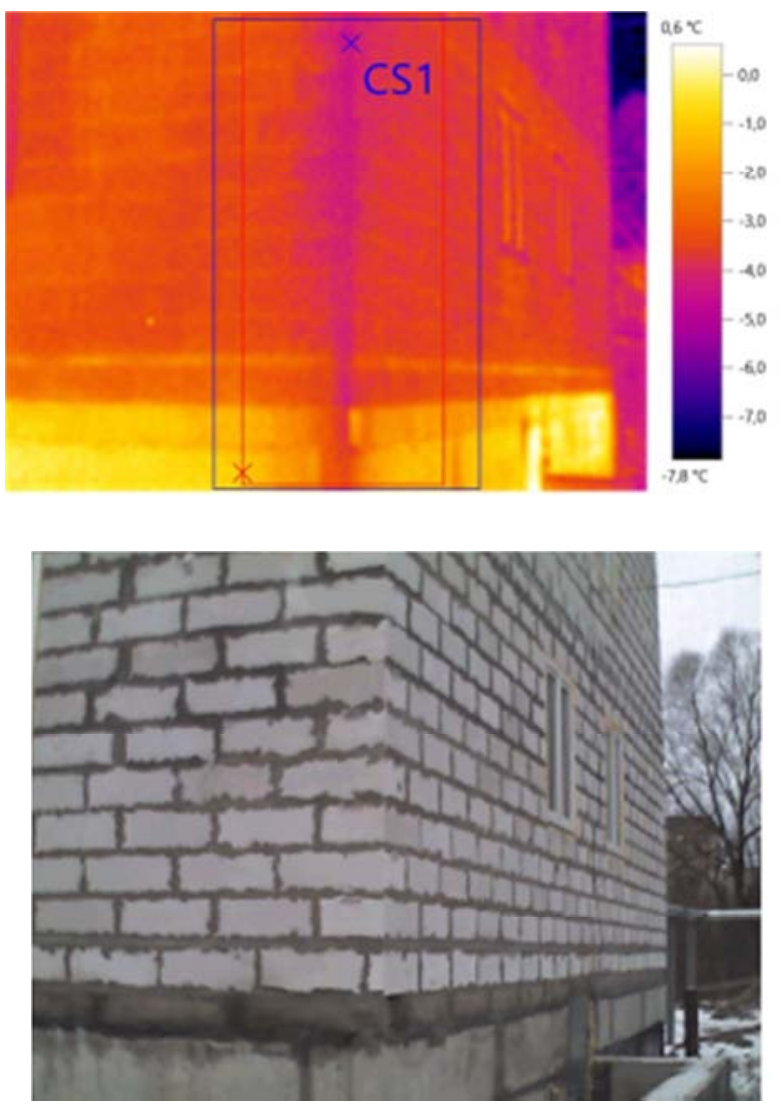

Figure 4. Corner zone.
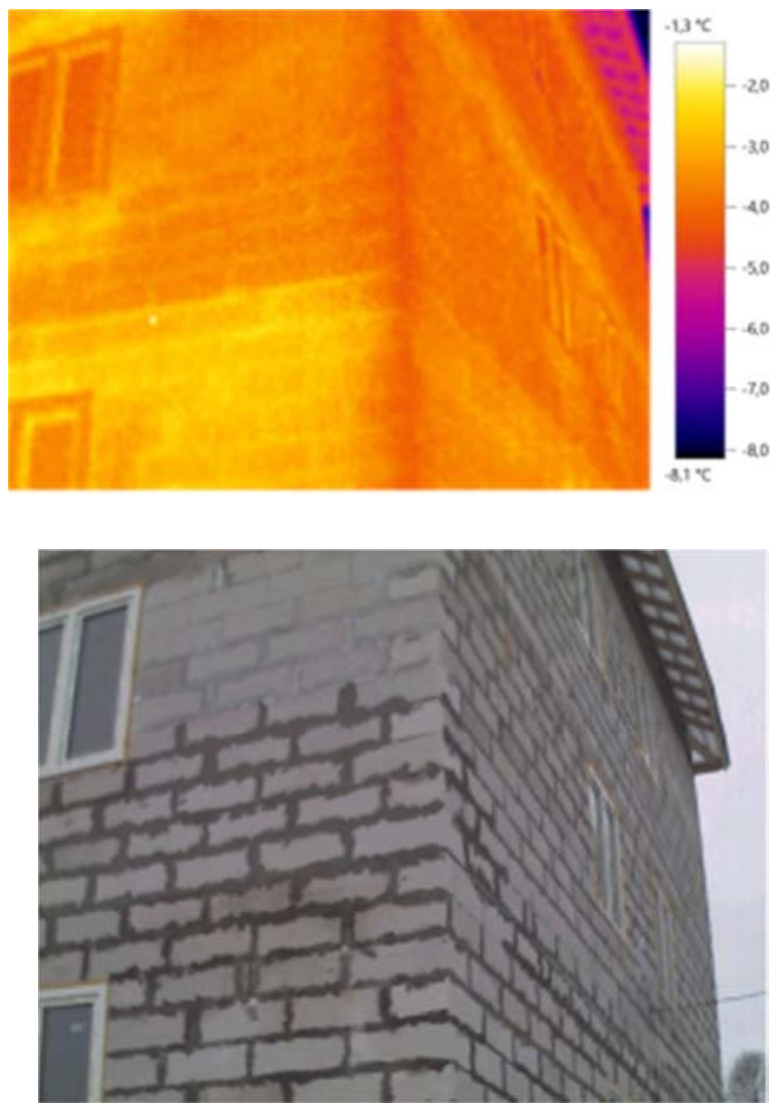

Figure 5. Heat-conducting fractions as brickwork joints.
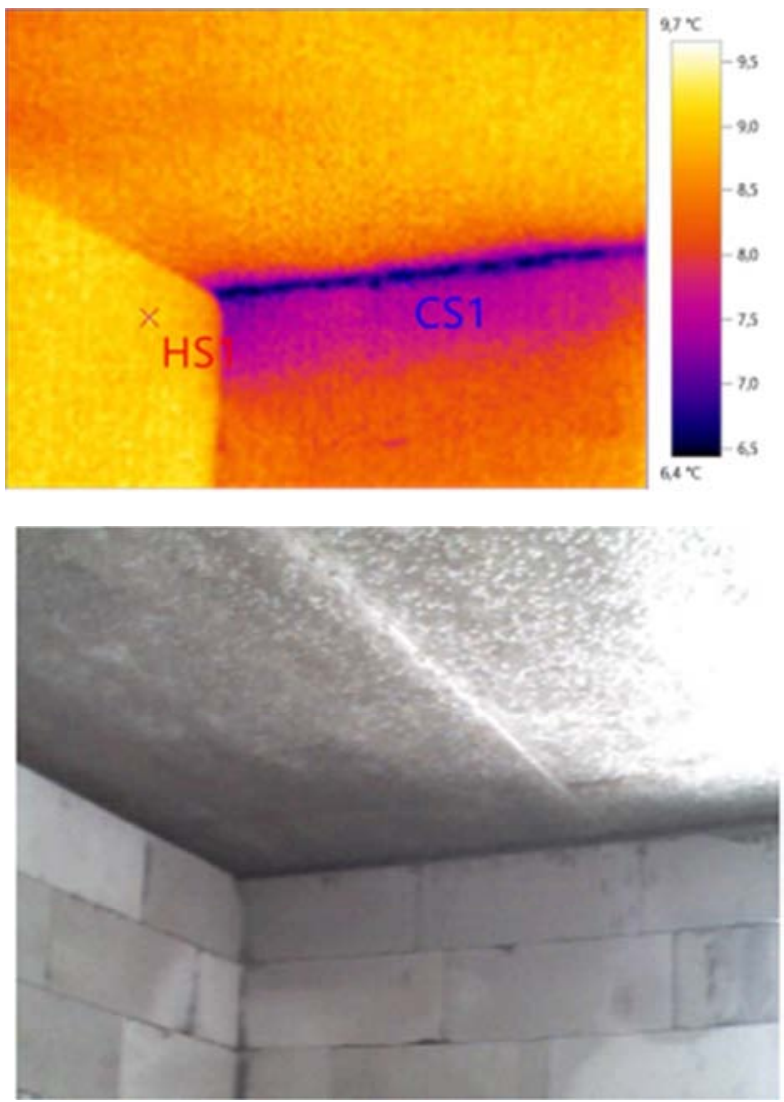

Figure 6. External wall and floor slabs conjunction zone.

Estimated climate data of the region of construction are presented in table 1 .

Table 1. Estimated Climate condition data.

\begin{tabular}{llll}
\hline Indicator & Variable & $\begin{array}{l}\text { Unit of } \\
\text { measurement }\end{array}$ & $\begin{array}{l}\text { Estimated } \\
\text { value }\end{array}$ \\
\hline $\begin{array}{l}\text { Average temperature of outdoor air } \\
\text { during heating period }\end{array}$ & $t_{\mathrm{h}}$ & ${ }^{\circ} \mathrm{C}$ & $-1,3$ \\
$\begin{array}{l}\text { Duration of heating period } \\
\text { Heating period }\end{array}$ & $z_{\mathrm{h}}$ & day/year & 208 \\
$\begin{array}{l}\text { Estimated temperature of indoor } \\
\text { air }\end{array}$ & $H D D$ & ${ }^{\circ} \mathrm{C} \cdot$ day/year & 4430 \\
\hline
\end{tabular}

Project value of the heat transmission resistance of the external walls, made of air concrete blocks work without an additional insulation is assumed to be equal to $1,62 \mathrm{~m}^{2} \cdot \mathrm{K} / \mathrm{W}$.

Due to the finding out the thermal bridges during the thermal mapping survey, it was considered to be necessary to provide additional insulation of the external walls of the house: external walls of the building - with mineral wool slab on synthetic binding substance, on-the-ground part of the basement walls - with expanded polystyrene slabs.

The goal of research is to define the optimal thickness of the insulation layer. The optimization is done based on the calculation of heat energy losses through external walls of the apartment building before and after the facades insulation, as well as predicted payback period estimation for investments aimed to insulate external walls of the house considered, for various thickness of the additional thermal insulation layer $(50,60,70,80,90,100,110,120,130,140,150,160,170$, 
$180,190,200,250,300$ and $350 \mathrm{~mm})$.

\section{Main Body}

\subsection{Description of Elements of the Façade System}

Based on technical - economical comparison of the most wide spread and available for the chosen region of construction facades options, for the house considered the system of plaster façade Weber.therm comfort (figure 7) was accepted, with use of heat insulation details of mineral (glass) wool on synthetic binding substance.

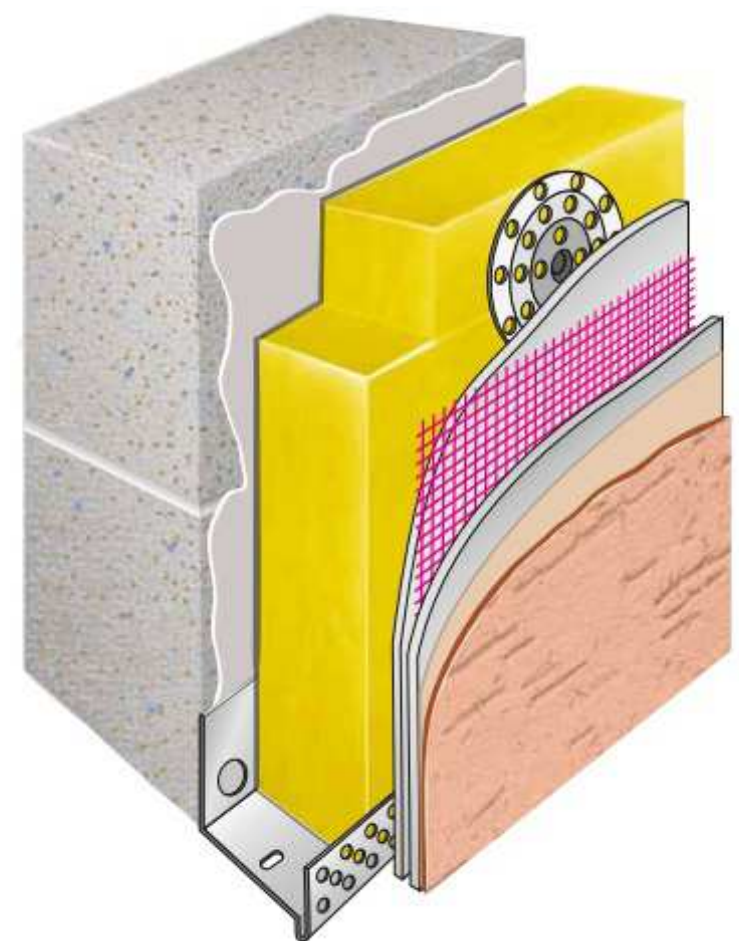

Figure 7. Schematic picture of Façade system Weber.therm comfort.

Figures 8 and 9 present the stages of facades works.

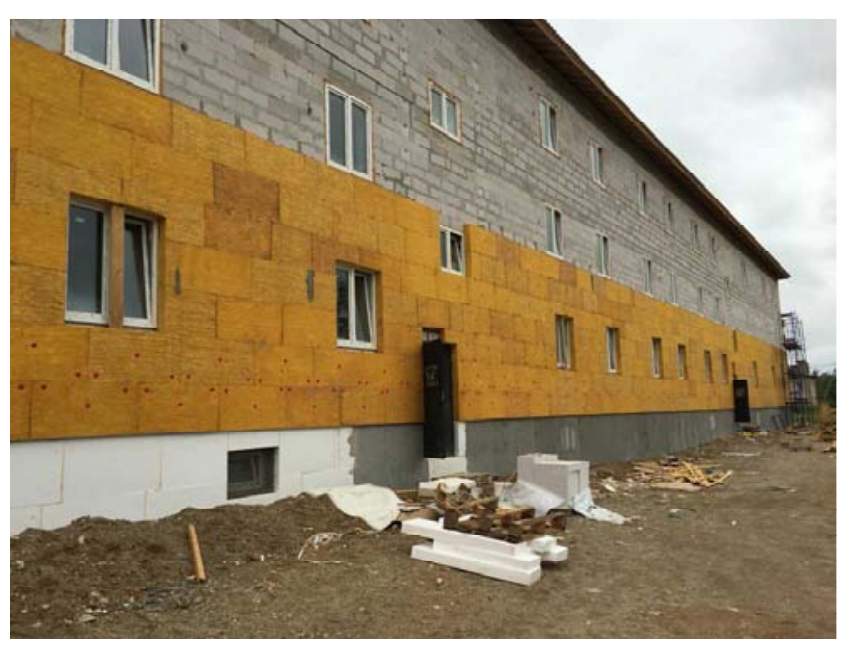

Figure 8. Heat insulation of the main façade of the building.

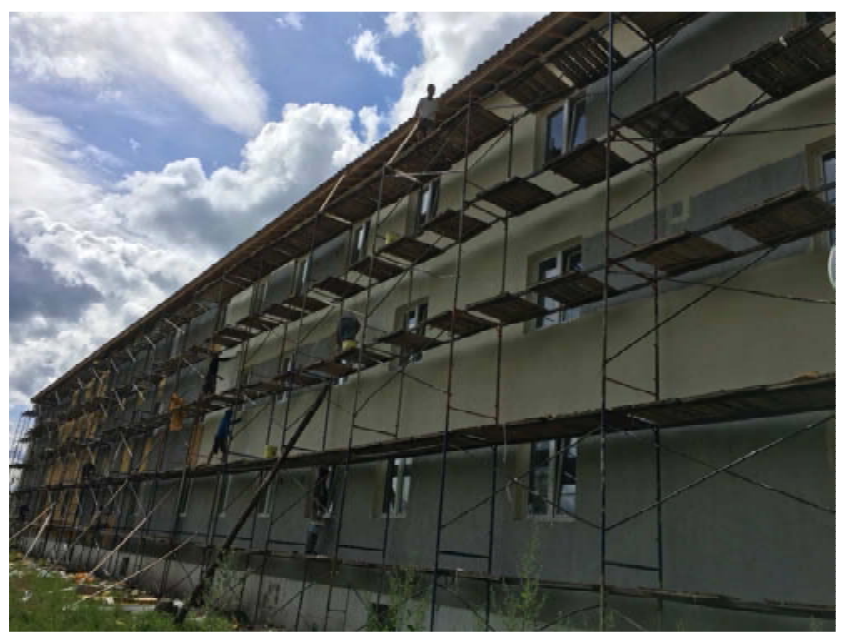

Figure 9. Finishing of the façade.

\subsection{Methodology}

For a heating period, average heating energy losses through the building facades can be calculated using the formula (1) below:

$$
Q=\frac{0,024 \cdot H D D}{R_{0} \cdot 1163} \cdot A_{f a c}
$$

where

$R_{0}$ - heat transmission resistance of external wall $\mathrm{m}^{2} \cdot \mathrm{K} / \mathrm{W}$

$H D D$ - heating degree day, ${ }^{\circ} \mathrm{C} \cdot$ day (table 1$) ;$

$0,024,1163$ - conversion coefficients;

$A_{\text {fac }}$ - façade area, $\mathrm{m}^{2}$.

In case of additional heat insulation of the facades, heat energy savings can be calculated using formula (2) below:

$$
\Delta Q=Q_{\text {bas }}-Q_{\text {ins }}=\left(\frac{1}{R_{0}^{\text {bas }}}-\frac{1}{R_{0}^{\text {ins }}}\right) \cdot \frac{0,024 \cdot H D D}{1163} \cdot A_{f a c},
$$

where

$R_{0}^{\text {bas }}$ - heat transmission resistance of the external wall basic option without taking into account an additional heat insulation, $\mathrm{m}^{2} \cdot \mathrm{K} / \mathrm{W}$;

$R_{0}^{i n s}$ - heat transmission resistance of the external wall basic option taking into account an additional insulation, $\mathrm{m}^{2} \cdot \mathrm{K} / \mathrm{W}$

0,024, HDD , 1163, $A_{f a c}-$ the same as in formula (1).

For initial (basic) value of the scaled heat transmission resistance the actually measured value was taken, i.e. $R_{0}^{\text {bas }}$ $=1,62 \mathrm{~m}^{2} \cdot \mathrm{K} / \mathrm{W}$.

The difference between the operation costs $C F$, which represents total losses through the considered type of external envelope before and after an additional heat insulation and expressed in terms of money, rubles, can be calculated using formula $(1,2)$ : 


$$
C F=\Delta Q \cdot c_{h}=\left(\frac{1}{R_{0}^{\text {bas }}}-\frac{1}{R_{0}^{\text {ins }}}\right) \frac{0,024 \cdot H D D \cdot A_{\text {fas }}}{1163} \cdot c_{h},
$$

where

$\Delta Q, R_{0}^{\text {bas }}, R_{0}^{\text {ins }}, H D D, A_{\text {fas }}$ - the same as in formulas (1), (2);

$c_{h}$ - heat energy tariff rate, rub/Gkal.

In construction usually the simple payback period of energy saving investments is calculated:

$$
S P P=\frac{I C_{0}}{C F},
$$

where

$I C_{0}$ - value of the invested capital, rubles;

$C F$ - annual costs reduction as a result of energy saving measure implementation, rub/year; when facades heat insulation is undertaken it is calculated by formula (3).

It should be mentioned that payback period calculated with formula (4) is obtained without taking into consideration:

(1) growth rate of heating energy tariffs;

(2) loan interest rates (in case of using a loan for heating insulation of the external walls of the building);

(3) discounted future cash inflows obtained as a result of the considered energy saving measure implementation and cut of the heating energy losses.

Due to that reason, the calculated value of the predicted payback period of investments using formula (4) should be considered as an estimation.

Taking into account additional factors mentioned above, predicted discounted payback period $D P P$ for investments aimed to additional heat insulation of facades of the considered building is calculated by the equation [14, 15]:

$$
D P P=\frac{\ln \left[1+\frac{I C_{0}}{C F} \cdot \frac{r-i}{1+i}\right]}{\ln \left[\frac{1+r}{1+i}\right]}=\frac{\ln \left[1+S P P \cdot \frac{r-i}{1+i}\right]}{\ln \left[1+\frac{(r-i)}{(1+i)}\right]},
$$

where

$I C_{0}, C F, S P P$ - are the same as in formula (4), rubles;

$r-$ average annual growth rate of heating energy tariffs;

$i$ - interest discount rate.

In reference [14] the equation (5) is considered in more detail.

If a construction company or an individual is using own money for facades heat insulation works, than capital costs will be equal estimated costs $I C_{0}$. In case when borrowed funds (bank loan) is used, with annuity monthly installments total investments in energy saving should be calculated using the formula (6) below:

$$
I C_{l}=m \cdot A \cdot I C_{0},
$$

$m$ - number of installments periods (for example, if the loan is taken for one year, $\mathrm{m}=12$, for two years $-\mathrm{m}=24$ and etc.)

$A$ - annuity coefficient;

$I C_{0}$ - investments equal estimated costs of works for facades heat insulation (without taking into account loans installments).

Annuity coefficient is calculated by formula (7):

$$
A=\frac{p_{l} \cdot\left(1+p_{l}\right)^{m}}{\left(1+p_{l}\right)^{m}-1}
$$

where

$p_{l}$-bank monthly interest rate on loan, expressed in $1 / 100$ over the number of installment periods (for example, for a $6 \%$ interest rate with monthly installments: $p_{l}$ $=0,06 / 12=0,005$ );

$m$ - the same as in formula (6).

Therefore, the equation (5) allows to estimate payback period $D P P$ of the considered energy saving measure with account for the total capital costs $I C_{l}$, loan installment payments $\left(p_{l}\right)$, tariffs growth rate for heating energy $(r)$, future cash flows discounting $(i)$, achieved by the cost cut as a result of this energy saving measure.

For this research, the funds for facades heat insulation were provided by Global Ecological via Development Programme (UNDP-GEF) with participation of UNDP-GEF 00074315 «Energy efficiency of building on North-West of Russia», and capital costs are considered without account for loan interest rate.

Average value of relative tariffs growth rate for heating energy for households in Russia $\Delta c_{h}$ is $15 \%$ per annum. Therefore, average annual growth rate of heating energy $r$ in formula (5) is taken to be equal 0,15 .

For future cash flows discounting rate, one can choose average inflation rate for certain period (e.g. 5 or 10 last years), Central Bank interest rate, income rate on alternative investments (e.g. time deposit in a bank), other factors influencing future cash flows value.

For this model, Central Bank interest rate is taken as a discounting rate, and it equals $11 \%$ (at the time of the construction of the building). Due to that, discounting rate $i$ in formula (5) is assumed to be equal 0,11 .

The best option of the additional heating insulation of facades will be the one for which the following condition will be achieved:

$$
D P P=f\left(\delta_{\text {ins }}\right) \rightarrow \min ,
$$

i.e., the option with the minimal payback period of the additional investments.

Scaled heat transmission resistance of external walls with account for an additional heating insulation layer is calculated by formula (9):

where 


$$
R_{0}^{i n s}=\left(R_{0}^{b a s}+\frac{\delta_{\text {ins }}}{\lambda_{\text {ins }}}\right) \cdot r_{t b},
$$

where

$R_{0}^{\text {bas }}$ - the same as in formula (4), $\mathrm{m}^{2} \cdot \mathrm{K} / \mathrm{W}$;

$\delta_{i n s}-$ thickness of an additional heat insulation layer, $\mathrm{m}$;

$\lambda_{\text {ins }}-$ thermal transmission of heat insulation layer, $\mathrm{W} /(\mathrm{m} \cdot \mathrm{K})$;

$r_{t b}-$ coefficient of thermotechnical homogeneity of an additional heating insulation layer.

Heat transmission resistance of the initial external walls option $R_{0}^{\text {bas }}$ is assumed to be equal $1,62 \mathrm{~m}^{2} \cdot \mathrm{K} / \mathrm{W}$.

Thickness of an additional heat insulation layer $\delta_{i n s}$ is assumed to be consequently equal to $50,60,70,80,90,100$, $110,120,130,140,150,160,170,180,190,200,250,300$ and $350 \mathrm{Mм}$ (19 options of additional heat insulation).

Heat transmission $\lambda_{\text {ins }}$ of thermal insulation items of mineral (glass) wool, according to tests protocols provided by producers is taken to be equal to $0,043 \mathrm{~W} /(\mathrm{m} \cdot \mathrm{K})$.

Coefficient of thermotechnical homogeneity of external walls which takes into account thermal bridges $r_{t b}$ is taken to be equal to 0,8 .

Based on the data provided, estimated values of external walls thermal transmission resistances of the considered building with additional heating insulation for different thickness of heat insulation are presented in table 2 .

Table 2. Heat transmission resistance of the external walls with account for an additional heat insulation layer $R_{0}^{\text {ins }}$.

\begin{tabular}{ll}
\hline $\begin{array}{l}\text { Thickness of heat insulation } \\
\text { layer } \boldsymbol{\delta}_{\text {ins }}, \mathbf{m}\end{array}$ & $\begin{array}{c}\text { Heat transmission resistance } \\
\text { ins }\end{array} \mathbf{~ m}^{\mathbf{2}} \cdot \mathbf{K} / \mathbf{W}$ \\
\hline 50 & 2,23 \\
60 & 2,41 \\
70 & 2,60 \\
80 & 2,78 \\
90 & 2,97 \\
100 & 3,16 \\
110 & 3,34 \\
120 & 3,53 \\
130 & 3,72 \\
140 & 3,90 \\
150 & 4,09 \\
160 & 4,27 \\
170 & 4,46 \\
180 & 4,65 \\
190 & 4,83 \\
200 & 5,02 \\
250 & 5,95 \\
300 & 6,88 \\
350 & 7,81 \\
\hline
\end{tabular}

As one can conclude from the data presented in table 2 , the minimum thickness of the heat insulation layer required to provide specified value of heat transmission resistance $(2,95$ $\mathrm{m}^{2} \cdot \mathrm{K} / \mathrm{W}$ ) is $90 \mathrm{~mm}$. However, it will not be necessary an optimal one from investing point of view.

\section{Results and Discussion}

\subsection{Capital Costs}

According to the original project data, facades area of the survey item (apartment building) is assumed to be equal $1162,77 \mathrm{~m}^{2}$.

Capital costs for Weber.therm comfort system assembling are presented in table 3.

Capital costs (in Russian rubles) include:

(1) cost of plaster materials of Weberthermsystem including fittings, with thickness of $200 \mathrm{~mm}-458,50$ $\mathrm{rub} / \mathrm{m}^{2}$

(2) cost of plaster materials of Weberthermsystem including fittings, with thickness of $200 \mathrm{~mm}$ and more, $-498,0 \mathrm{rub} / \mathrm{m}^{2}$;

(3) cost of system assembling works including related materials and charges $-1380,0 \mathrm{rub} / \mathrm{m}^{2}$.

Note: The ruble against the US dollar is about $65-68$ $\mathrm{rub} / \mathrm{USD}$.

Table 3. Capital costs for additional heat insulation of the basic option of external walls, rub.

\begin{tabular}{lll}
\hline $\begin{array}{l}\text { Thickness of heat } \\
\text { insulation layer } \boldsymbol{\delta}_{\boldsymbol{i n s}}, \mathbf{m}\end{array}$ & $\begin{array}{l}\text { Costs of insulation } \\
\mathbf{1} \mathbf{~ m}^{\mathbf{2}}, \mathbf{r u b} / \mathbf{m}^{\mathbf{2}}\end{array}$ & $\begin{array}{l}\text { Additional investments } \\
\boldsymbol{I} \boldsymbol{C}_{0}, \mathbf{r u b} .\end{array}$ \\
\hline 50 & 2038,50 & 2370306,65 \\
60 & 2084,50 & 2423794,07 \\
70 & 2131,14 & 2478025,66 \\
80 & 2176,93 & 2531268,90 \\
90 & 2203,69 & 2562384,62 \\
100 & 2248,50 & 2614488,35 \\
110 & 2293,31 & 2666592,07 \\
120 & 2338,13 & 2718707,42 \\
130 & 2379,89 & 2767264,70 \\
140 & 2425,72 & 2820554,44 \\
150 & 2468,50 & 2870297,75 \\
160 & 2511,28 & 2920041,05 \\
170 & 2554,06 & 2969784,35 \\
180 & 2602,94 & 3026620,54 \\
190 & 2645,72 & 3076363,84 \\
200 & 2688,50 & 3126107,15 \\
250 & 2948,00 & 3427845,96 \\
300 & 3168,00 & 3683655,36 \\
350 & 3388,00 & 3939464,76 \\
\hline
\end{tabular}

The costs include costs of assembling works of the facade system with account for costs of assembling all elements of the façade system, building timber, fastener and other costs.

Note: Presented capital costs of façade system heat insulation are valid for North-West Region of Russia. Costs of materials - market price for wholesale type of customers. Costs of works complies with the average at the market. Costs of materials and works may be reduced by setting a tender for every object separately.

\subsection{Exploitation Costs}

Exploitation costs before and after additional heat insulation of external walls basic with various thickness of heat insulation layer (19 options of additional heat insulation) are calculated using formula (3) and can be found in table 4 . Exploitation costs in table 4 equal to the total heating energy 
losses through the walls during one normalized heating period $\left(H D D=4430{ }^{\circ} \mathrm{C} \cdot\right.$ day $)$. Tariff rate for heating energy in

Porkhov is $1838,5 \mathrm{rub} / \mathrm{Gcal}$.

Table 4. Difference between losses of heating energy through building envelope before and after the heat insulation of basic option of external walls of the building, rub/year.

\begin{tabular}{lll}
\hline Thickness of heat insulation layer $\boldsymbol{\delta}_{\text {ins }}, \mathbf{m}$ & Heat transmission resistance, $\mathbf{~ m}^{\mathbf{2}} \mathbf{K} / \mathbf{W}$ & Difference of operation costs $\boldsymbol{C} \boldsymbol{F}, \mathbf{r u b} / \mathbf{y e a r}$ \\
\hline 50 & 2,23 & 32999,14 \\
60 & 2,41 & 39544,65 \\
70 & 2,60 & 45470,57 \\
80 & 2,78 & 50337,41 \\
90 & 2,97 & 54834,64 \\
100 & 3,16 & 58791,06 \\
110 & 3,34 & 62124,03 \\
120 & 3,53 & 65273,42 \\
130 & 3,72 & 68101,09 \\
140 & 3,90 & 70525,79 \\
150 & 4,09 & 72853,65 \\
160 & 4,27 & 74867,90 \\
170 & 4,46 & 76817,68 \\
180 & 4,65 & 78608,11 \\
190 & 4,83 & 80174,38 \\
200 & 5,02 & 81705,80 \\
250 & 5,95 & 87790,72 \\
300 & 6,88 & 92230,59 \\
350 & 7,81 & 95613,08 \\
\hline
\end{tabular}

\subsection{Discounted Payback Period}

Predicted values of additional costs for heat insulation payback periods for various thickness of heat insulation layer are calculated using formula (5) and presented in table 5.

Table 5. Discounted payback period of additional investments, aimed for facades heat insulation of the considered apartment building depending on thickness of heat insulation layer.

\begin{tabular}{llll}
\hline $\begin{array}{l}\text { Thickness of heat insulation } \\
\text { layer } \boldsymbol{\delta}_{\text {ins }}, \mathbf{m}\end{array}$ & $\begin{array}{l}\text { Additional capital costs } \boldsymbol{I C}_{\mathbf{0}}, \\
\text { rub }\end{array}$ & $\begin{array}{l}\text { Difference of operation costs } \\
\boldsymbol{C F}, \text { rub/year }\end{array}$ & Discounted payback period $\boldsymbol{D P P}$, years \\
\hline 50 & 2370306,65 & 32999,14 & 36,1 \\
60 & 2423794,07 & 39544,65 & 32,9 \\
70 & 2478025,66 & 45470,57 & 30,7 \\
80 & 2531268,90 & 50337,41 & 29,2 \\
90 & 2562384,62 & 54834,64 & 27,9 \\
100 & 2614488,35 & 58791,06 & 27,0 \\
110 & 2666592,07 & 62124,03 & 26,4 \\
120 & 2718707,42 & 65273,42 & 25,9 \\
130 & 2767264,70 & 68101,09 & 25,5 \\
140 & 2820554,44 & 70525,79 & 25,2 \\
150 & 2870297,75 & 72853,65 & 25,0 \\
160 & 2920041,05 & 74867,90 & 24,8 \\
170 & 2969784,35 & 76817,68 & 24,7 \\
180 & 3026620,54 & 78608,11 & 24,6 \\
190 & 3076363,84 & 80174,38 & $24,5(24,52)^{*}$ \\
200 & 3126107,15 & 81705,80 & $24,5(24,48)^{*}$ \\
250 & 3427845,96 & 87790,72 & 24,8 \\
300 & 3683655,36 & 92230,59 & 25,2 \\
350 & 3939464,76 & 95613,08 & 25,7 \\
\hline
\end{tabular}

*Note: In brackets one can find discounted payback period value $D P P$, rounded to second decimal

The results presented in table 5, are shown at figure 10 . 


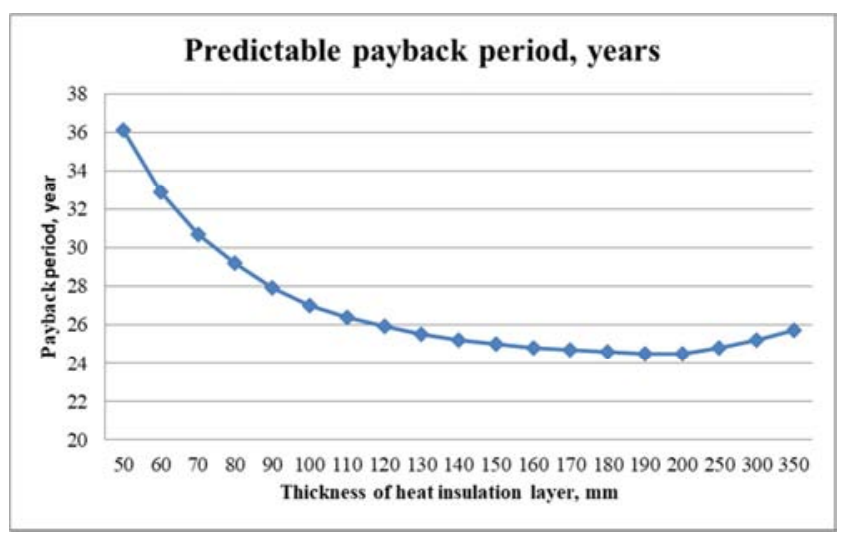

Figure 10. Dependency graph of discounted payback period of facades heat insulation investments and thickness of additional heat insulation layer.

Note: calculations presented above are valid when there is an automatic heating point with automatic control of heat carrying agent in apartment building.

As can be concluded from the data presented in table 5, condition (8) is optimally fulfilled with thickness equals 190 and $200 \mathrm{~mm}$, i.e., with these thicknesses predicted payback period of additional investments for heat insulation of the considered apartment building is minimal.

If costs of external walls pargeting works as well as finishing materials costs are not taking into consideration for calculation of investments payback, the predicted payback period will be reduced by half.

\section{Conclusion}

Predicted payback period of investments aimed to additional heating insulation of external walls of the considered apartment building is estimated to be between 24,5 and 36,1 years depending on thickness of an additional heating insulation layer.

Minimal predicted payback period of investments in heat insulation of the facades is 24,5 years with heat insulation layer thickness of $200 \mathrm{~mm}$. Thickness of heat insulation layer of $200 \mathrm{~mm}$ for considered apartment building complies with condition (8) to the fullest extent possible.

\section{References}

[1] Benati S. An optimization model for stochastic project networks with cash flows. Computational Management Science 3. 2006. No. 4. Pp. 271-284.

[2] Elmaghraby S. E. On the fallacy of averages in project risk management. European Journal of Operational Research. 2005. No. 165. Pp. 307-313.

[3] Elmaghraby S. E., Herroelen W. S. The scheduling of activities to maximize the net present value of projects. European Journal of Operational Research. 1990. No. 49. Pp. $35-49$.

[4] Elmaghraby S. E., J. Kamburowski On project representation and activity floats. Arabian Journal of Science and Engineering. 1990. No. 15. Pp. 626-637.

[5] Herroelen W. S., Dommelen P. V., Demeulemeester E. L. Project network models with discounted cash flows - A guided tour through recent developments. European Journal of Operational Research. 1997. No. 100. Pp. 97-121.

[6] Herroelen W. S., Leus R. Project scheduling under uncertainty: Survey and research potentials. European Journal of Operational Research. 2005. No. 165. Pp. 289-306.

[7] Özdamar L., Dündar H. A flexible heuristic for a multi-mode capital constrained project scheduling problem with probabilistic cash inflows. Computers and Operations Research. 1997. No.24. Pp.1187-1200.

[8] Rockafellar R. T., Uryasev S. Optimization of conditional value-at-risk. Journal of Risk. 2000. No.2. Pp. 21-41.

[9] Stephan K., Menassa C. Modeling the Effect of Building Stakeholder Interactions on Value Perception of Sustainable Retrofits. Journal of Computing in Civil Engineering. 2014. No. 3. Pp. 68-78.

[10] Bond S., Mitchell P. Alpha and persistence in real estate fund performance. Journal of Real Estate Finance. 2010. No. 41. Pp. 53-79.

[11] Kaplan S., Schoar A. Private equity performance: Returns, persistence, and capital flows. Journal of Finance. 2005. No. 60. Pp. 1791-1823.

[12] De Santoli, L., Fraticelli, F., Fornari, F., Calice, C. Energy performance assessment and a retrofit strategies in public school buildings in Rome. Energy and Buildings. 2014. No. 68. Pp. 196-202.

[13] Corrado, V., Murano, G., Paduos, S., Riva, G. On the Refurbishment of the Public Building Stock Toward the Nearly Zero-energy Target: Two Italian case studies. Energy Procedia. 2016. No. 101. Pp. 105-112.

[14] Gorshkov A. S., Vatin N. I., Rymkevich P. P., Kydrevich O. O. Payback period of investments in energy saving. Magazine of Civil Engineering. 2018. No. 2. Pp. 65-75.

[15] Gorshkov A. S. Model of Evaluating the Projected Payback Period in Energy Preservation. Vestnik MGSU [Proceedings of Moscow State University of Civil Engineering]. 2015. No. 12. Pp. 136-146. 